\title{
Creating new populations of Apium bermejoi (Apiaceae), a critically endangered endemic plant on Menorca (Balearic Islands)
}

\author{
Juan Rita" \& Joana Cursach \\ Dep. de Biología, Universitat de les Illes Balears, ctra. Valldemossa km 7,5, E-07122 Palma de Mallorca, Spain \\ jrita@uib.es; joana.cursach@uib.es
}

\begin{abstract}
Rita, J. \& Cursach, J. 2013. Creating new populations of Apium bermejoi (Apiaceae), a critically endangered endemic plant on Menorca (Balearic Islands). Anales Jard. Bot. Madrid 70(1): 27-38.

Apium bermejoi is a stoloniferous plant endemic to the island of Menorca (Balearic Islands). It is found only at one locality, and it is listed as Critically Endangered (according to the IUCN criteria). We describe the main results of population restoration actions undertaken under the Recovery Plan for this species, including the following: 1) introduction at two new localities (2008), 2) reinforcement of the original wild and the introduced populations, and 3) a programme for monitoring population dynamics (including both wild and introduced populations) spanning four years (2006-2010). The plant material for the introduction and reinforcement projects was generated from seeds gathered in the wild. We carried out a monthly census of all of the individuals/patches and emerged seedlings, from which we assessed their survival at 3-4months. The survival rates of the planted individuals in the two new localities after three months were found to be $59.0 \%$ and $56.3 \%$, and more than $80 \%$ of the surviving plants produced fruits. A seasonal pattern was observed based on the minimum cover values recorded in the censuses taken at the end of summer, with an increase detected during autumn, and maximal cover values recorded during May/June. The $A$. bermejoi populations showed large inter-annual fluctuations in both the number of patches and area of occupancy. The number of seedlings varied across the study years, and their survival was linked to specific meteorological events, such as severe storms and dry and hot spells during autumn. The initial phase of introduction for this species has been overall successful, but a final evaluation can only be made on a longterm basis.
\end{abstract}

Keywords: conservation biology, reintroduction, threatened species, population dynamics, seedling survival, Mediterranean flora.

\section{INTRODUCTION}

Population restoration techniques have become widely used tools for the conservation of threatened plant species in recent decades (Maunder, 1992; Hodder \& Bullock, 1997; Escudero \& Iriondo, 2003; Heywood \& Iriondo, 2003; Godefroid \& al., 2011). The IUCN (1998) states that a "reintroduction" is an attempt to establish a species in an area that was part of its range in the past, while a "benign introduction" (hereafter, introduction) is the attempt to establish a species, for purposes of conservation, outside of its range, but in an appropriate habitat and eco-geographical area. Many authors use the term "reintroduction" in a broad sense (s.l.) to refer to any attempt to establish plant material in a natural area (Godefroid \& al., 2011). Reintroductions s.l. (hereafter, reintroductions) were not considered to be an effective tool for the conservation of endangered species in the past, but due to the extensive experience gained in recent decades, their potential has been re-examined (Fahselt, 2007). The main goal

\section{Resumen}

Rita, J. \& Cursach, J. 2013. Creación de nuevas poblaciones de Apium bermejoi (Apiaceae), un endemismo críticamente amenazado en Menorca (Islas Baleares). Anales Jard. Bot. Madrid 70(1): 27-38 (en inglés).

Apium bermejoi, planta estolonífera endémica de Menorca (Islas Baleares), de la que se conoce una sola localidad en el medio natural, está considerada en Peligro Crítico de extinción (según criterios UICN). Se presentan los principales resultados de las acciones de restauración de las poblaciones previstas en el Plan de Recuperación de esta especie que, entre otras, constaba de: 1) introducción en dos nuevas localidades (2008), 2) reforzamiento de la población original y 3) programa de seguimiento de la dinámica de todas las poblaciones (naturales e introducidas) a lo largo de 4 años (2006-2010). Para la introducción y reforzamiento se utilizaron plantas germinadas a partir de un lote de semillas de la población original. Se realizaron censos mensuales de todos los individuos/manchas y de las plántulas emergidas, de éstas se evaluó su supervivencia a los 3-4 meses. La supervivencia de los individuos plantados a los tres meses fue del 59,0\% y del $56,3 \%$ en las dos nuevas localidades; más del $80 \%$ de estas plantas fructificaron. Se observó un patrón estacional con valores de cobertura mínimos en los censos de finales de verano, incrementos durante el otoño y valores máximos en el censo de mayo/junio. Las poblaciones presentaron una elevada fluctuación interanual tanto en número de individuos/manchas como en cobertura. El número de plántulas emergidas fue muy variable entre años, su número y supervivencia se relacionó con eventos meteorológicos puntuales, como lluvias torrenciales y periodos secos y cálidos durante el otoño. La fase inicial de las introducciones ha sido globalmente exitosa, aunque la evaluación final deberá hacerse a largo plazo.

Palabras clave: biología de la conservación, reintroducción, especie amenazada, dinámica poblacional, supervivencia de plántulas, flora mediterránea.

of reintroduction is to establish a viable population under minimal long-term management (Seddon, 1999). The Re-introduction Specialist Group of the IUCN's Species Survival Commission (IUCN, 1998) has developed guidelines to allow reintroductions to achieve conservation goals.

Any reintroduction ideally requires a thorough understanding of the biology of the species involved (e.g., its growth form, mating system, fertility, germination) including its genetic and ecological characteristics (e.g., the amount and distribution of genetic variation, habitat requirements, mechanisms of dispersion, symbiotic relationships, pests and diseases) and the conservation status of wild populations (Falk \& al., 1996; Guerrant \& Pavlik, 1998). In addition, previous experiences can contribute significantly to the design of new protocols for reintroduction.

The criteria and methods for reintroduction have been analysed by different authors (Fiedler \& Laven, 1996; Guerrant \& Pavlik, 1998; IUCN, 1998; Escudero \& Iriondo, 2003; Guerrant \& Kaye, 2007; Godefroid \& al., 2011), all of whom

\footnotetext{
* Corresponding author.
} 
emphasise that the study protocol should take into account 1) the selection of the planting area or plant material;2) the origin and type of material; 3 ) the size, spatial distribution and genetic structure of the new population; and 4) the method for monitoring the undertaken action. In the short term, the success of reintroductions can be assessed based on survival (establishment), reproduction and dispersal ratios (Pavlik, 1996). Thus, recruitment is considered the most reliable parameter indicating a successful reintroduction because it reflects many components of the life cycle (Pavlik, 1996; Sutter, 1996). However, the ultimate success of a reintroduction project, i.e., autonomous maintenance of populations, can be determined only after many years of follow-up (from 10 years to several decades) (Maunder, 1992; Pavlik, 1996; Milton \& al., 1999), depending on the generation time for the species.

A benign introduction is an action that is merits in situ actions when it makes a significant contribution to the conservation of a species and when there is no possibility of reintroducing the species to sites it inhabited historically (IUCN, 1998). Species that are found at a unique locality in the wild fall into this category (Maunder, 1992). In these cases, even when imminent threats are unknown it is advisable to diversify the risk by increasing the single population to a minimum of three subpopulations (Martinell \& al., 2011). Benign introductions are also advisable for species that are on the verge of extinction, especially if they are subject to strong population oscillations and / or there are imminent threats (Escudero \& Iriondo, 2003; Colas et al., 2008).

These techniques have been subjected to some debate because of the existence of certain risks, such as an alteration of allelic proportions in the genome among populations or processes increasing inbreeding depression (Escudero \& Iriondo, 2003). On other hand, there are many cases where reintroductions do not reach the desired objectives for diverse reasons, including a lack of knowledge about the species biology in question (Alboucaya \& al. 1999, Godefroid \& al., 2011), poor financial support or timetables that are too brief or "short-lived" (Fiedler \& Laven, 1996). In addition, many negative experiences remain unpublished, such that a review of the scientific literature does not allow an accurate assessment of the actual success that these techniques have achieved (Godefroid \& Vanderborght, 2011; Godefroid \& al., 2011). Paradoxically, not taking action in critical cases can represent an equal or greater risk (the extinction of a species in the worst case scenario) compared to an attempt to restore the original population (Maunder, 1992), so that managers are often taking a risk whatever decision is reached.

There is a long experience with introductions and reintroductions s. str. in Spain, although documentation of such processes did not begin until the last decades of the twentieth century (see, for example, Sainz-Ollero \& Hernández-Bermejo, 1979; Escudero \& Iriondo, 2003). Furthermore, much of the experience gained in Spain remains unpublished, as in the rest of the world (Godefroid \& Vanderborght, 2011). In the Balearic Islands, the first attempted introduction was Ranunculus weyleri Marès ex Willk., endemic to Majorca, in a new locality in the Serra de Tramuntana in 1958 (J.J. Orell, per. comm.), where this species still occurs (Cursach \& Rita, 2012 b). Another notable case is that of Lysimachia minoricensis J.J.
Rodr., a plant endemic to Menorca Island which became extinct in the wild, and which, from the 1960s to the present, has been successively reintroduced and introduced, but with little success (Fraga, 2000; Valdés, 2011), most likely due to a poor knowledge of the ecological requirements of this species and its low ex situ population genetic diversity (Ibáñez \& al., 1999). More recently, the environmental authority of the Balearics (Govern de les Illes Balears) has attempted several reintroductions of threatened species, such as the introduction of Euphorbia margalidiana Kuhb. \& Lewej., which is endemic to a single islet north of Ibiza, in a new location (Mayol $\&$ al., 2011); the introduction of Pinus pinaster Aiton in new localities in Menorca from a small local population that disappeared after a fire; and the reinforcement of several endangered species of the genus Limonium in Mallorca (Moragues \& Mayol, 2011).

On the island of Menorca, approximately 30 species of plants are currently protected by international or national laws, 11 of which are endemic. According to Royal Decree 139/2011, only Lysimachia minoricensis J.J. Rodr. and Apium bermejoi Llorens are classified as Endangered, while three other species are considered Vulnerable. However, a regional decree 75/2005 included Pinus pinaster Aiton in the Critically Endangered category, with six additional species in other categories of protected endangered plants.

Apium bermejoi L. Llorens 1982 [= Helosciadium bermejoi (L. Llorens) Popper \& MF Watson (Ronse \& al., 2010)] is an endemic species of Menorca. It is considered Critically Endangered according to the criteria of the IUCN (Moreno, 2008) and is legally protected at both the national (National Catalogue of Endangered Species, Royal Decree 139/2011) and international levels (Appendix I of the Bern Convention and Annexes II, 1991, and IV of the Habitats Directive of the Council of Europe, 1992). Moreover, it is considered to be one of the 50 most endangered plant species in the Mediterranean islands (Montmollin \& Strahm, 2007). In 2008 the Govern de les Illes Balears approved the "Recovery Plan of Apium bermejoi" (BOIB No. 65 of 15.05.2008), which is based on a previous Conservation Plan developed under the LIFE project "Conservation of areas with threatened species of flora on the island Menorca" (LIFE2000/NAT/e/7355) (Mus \& al., 2003).

Apium bermejoi inhabits one small locality on the northeastern coast of Menorca that is divided into two subpopulations. Prior to this study, the available demographic data covered only the period from 1999-2002 (Mus \& al., 2003) during which the population was very much in flux, and the number of mature individuals never exceeded one hundred. Given the small size of the only natural population of $A$. bermejoi, its extinction risk was considered very high, and it was considered necessary, in addition to applying ex situ conservation techniques, to introduce the species in new locations. To this end, we conducted a pilot project in 2005 following the criteria of a prior Introduction Plan (Rita \& Cardona, 2004a), and also with an reinforcement of the original population in 2007 . In 2008 , the species was introduced into two new locations, using procedures in accordance with the provisions of the Recovery Plan for $A$. bermejoi.

A. bermejo $i$ is a species that met all of the criteria as being considered at risk, and therefore the attempt to conduct be- 
nign introductions was not only acceptable but seems an advisable action for this species. These introductions allowed us to reduce the risk of extinction due to stochastic threats (demographic and environmental) by increasing the number of subpopulations and the overall size of the population. Moreover, this decision was made after evaluation and the approval of the Introduction Project (Rita \& Cardona, 2004a) by the Scientific Committee created ad hoc for the supervision of the LIFE 2000NAT/E/7355 project.

The introductions described in this article were carried out following studies that provided information on the reproductive biology (Rita \& Cardona, 2004b) and genetic variability (Rosselló, 2004) of the target species. All of this information facilitated the collection of seeds and planting of new populations while minimising the risk of genetic impoverishment. The selection of the planting area was conducted after some previous small-scale trials and with the knowledge acquired through ex situ cultivation. We sought a habitat as similar as possible to the original locality of the species, although this is a debatable criterion in species known from a single locality, as their survival at this site does not necessarily indicate that it corresponds to the optimal habitat. The selection of sites in protected areas and with the permission of the property owners provided the necessary guarantees of the long-term preservation of these places.

This report sets out the criteria and methods used for the introduction of $A$. bermejo $i$ in new localities and the results of monitoring both the new and the original populations in terms of population dynamics for four years (2006-2010). The success of the introductions was assessed based on the survival, and the flowering and fruiting ratios recorded among the planted individuals. Additionally, we evaluated the total number of seedlings emerging annually, their survival rate, and the relationship of such survival to environmental factors; we also assessed the number and cover of individuals/patches throughout the study period in all populations. Finally, we examine the current global state of conservation of this threatened species.

\section{MATERIAL AND METHODS \\ Study species}

A. bermejoi is a small stoloniferous plant (1-4 cm in height), initially presenting leaves in rosettes (Fig. 1), but subsequently showing a caespitose growth form. Its flowers are approximately $2.5 \mathrm{~mm}$ in diameter and are grouped in simple umbels. This species disperses via geoautochory. At the nodes of the stolons it forms rosettes of leaves that can become independent of the main rosette, constituting a efficient asexual propagation system. A. bermejoi has been described as a creeping hemicryptophyte (Llorens, 1982), and as a perennial herb (Knees, 2003), but under the current climate, it more often behaves as a therophyte because most of the plants die during summer. Despite its high potential for vegetative spread and asexual propagation, sexual reproduction is the main mechanism of reproduction in $A$. bermejoi, and most of its population is renewed every year from seeds (Rosselló, 2004; Cursach \& Rita, 2012a).

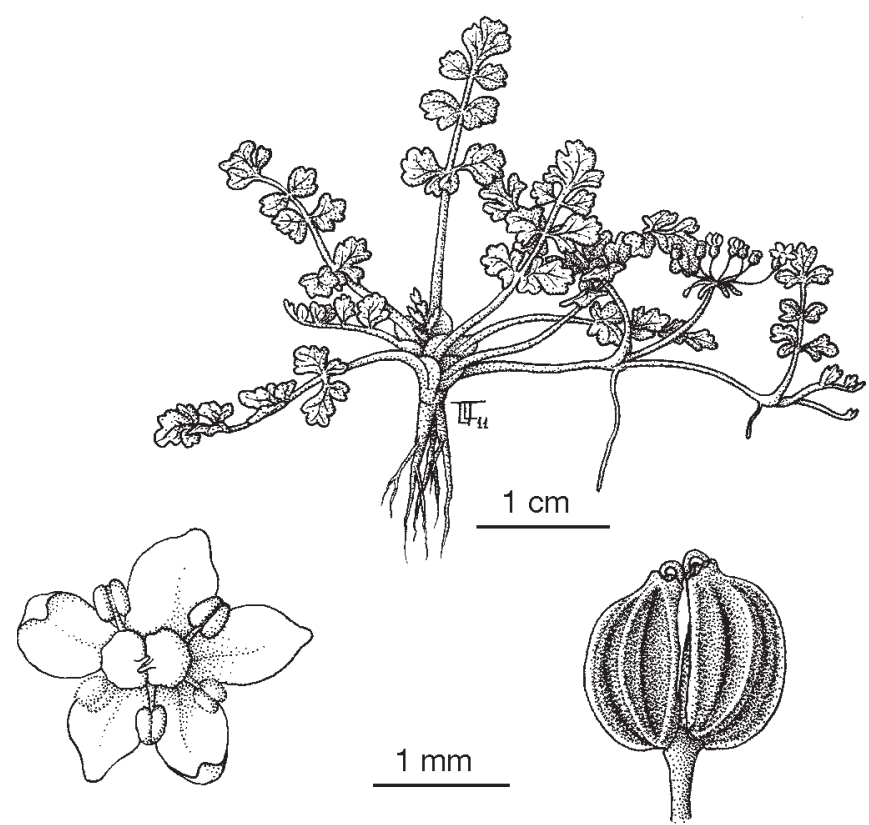

Fig. 1. Apium bermejoi: habit, flower and fruit. (Drawing: Lluís Fiol).

\section{Distribution and habitat description}

Menorca is an island of $702 \mathrm{~km}^{2}$ located in the western part of the Mediterranean basin, and the whole island was declared a Biosphere Reserve in 1993. There are two known natural subpopulations of $A$. bermejoi, located in small valleys separated by approximately $200 \mathrm{~m}$ in the coastal zone of Cap Negre $(\mathrm{CNe}$ and $\mathrm{CNe} 2)$, in the northeast of the island $\left(39^{\circ} 53^{\prime} \mathrm{N}, 4^{\circ} 18^{\prime} \mathrm{E}\right.$ ) (Fig. 2). The CNe subpopulation occupies approximately $50 \mathrm{~m}^{2}$, while the $\mathrm{CNe} 2$ subpopulation is very small (dispersed over $\sim 1 \mathrm{~m}^{2}$ ) and consists of less than 6 patches (see below). The major subpopulation of $A$. bermejoi occupies the humid sediment of a small seasonal stream that runs on a silicon substrate (Palaeozoic turbidites) at $50 \mathrm{~m}$ asl near a sea cliff. The impermeability of this substrate results in some areas remaining flooded during the rainy season (September to March), followed by complete dryness beginning in May (according to the rainfall in the spring) and during the summer. The soil cover is very thin, skeletal, and loosely structured, due to the frequent movement and accumulation of new materials and to the geological nature of the substrate itself. The orientation of the torrent favors the presence of shaded areas for much of the day. The area occupied by $A$. bermejoi is strongly influenced by the sea and the north wind, typically cold and dry, that prevails on the island. The climate is typically Mediterranean, characterised by seasonal variation of the photoperiod and high temperatures and low rainfall during the summer. The surrounding vegetation is tipically coastal and includes species such as Crithmum maritimum, Daucus carota ssp. commutatus and Limonium spp.

\section{Previous conservation measures}

Under the project LIFE2000NAT/E/7355, several studies were carried out addressing the population dynamics and reproductive biology of the target species (Mus \& al., 2003; Rita 


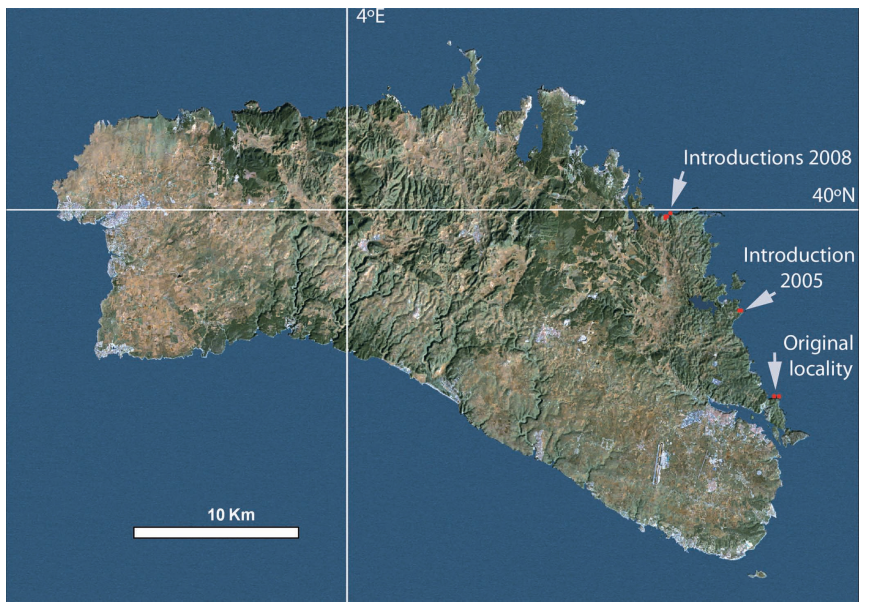

Fig. 2. Map of the island of Menorca (Balearic Islands, western Mediterranean) showing the distribution area of Apium bermejoi. Grids of $100 \mathrm{x}$ 100 m. (Illustration: José Castro).

\& Cardona, 2004a, 2004b; Rita \& al., 2005; Cursach \& al., 2009). Rosselló (2004) also conducted a study of molecular diversity using chloroplast (SSR) and nuclear (ISSR) markers. In the latter, using material obtained from most of the individuals of the original population $(1999,79$ individuals, and 2003, 29 individuals), the existence of a single chloroplast genotype was detected, suggesting that this species has suffered a demographic bottleneck in the past. In contrast, the nuclear genome of $A$. bermejoi showed high genetic variability among individuals (in 1999 and $2003,86.1 \%$ and $75.9 \%$ of individuals, respectively, could be identified by their genetic profile), indicating that the population was not genetically impoverished and largely reproduced via seeds.

In 2003 and in 2007, we collected seeds for conservation in genebanks, with between $5 \%$ and $10 \%$ of the seeds of each mature individual sampled. The seeds, keeping each individual separate so as to retain the traceability of parental origin, were stored under conditions of controlled humidity and temperature in the Seed Bank of the Sóller Botanical Garden.

As part of a pilot project aimed at the introduction of $A$. bermejoi in a new location (sa Cudia Nova $(\mathrm{CNo})\left(39^{\circ} 56^{\prime} \mathrm{N}\right.$, $4^{\circ} 16^{\prime} \mathrm{E}$ ) (Fig. 2), planting methods were tested in March 2004 at several points close to the original population (Rita \& Cardona, 2004b). The survival of individuals in these trials three months after planting was $81.6 \%(n=38)$, among which $71 \%$ flowered, and $58.1 \%$ fruited. Another introduction at $\mathrm{CNo}$ was conducted in March 2005 by planting 88 individuals, and the survival obtained three months later was $64.8 \%$, among which $75.4 \%$ of the plants flowered, and $52.6 \%$ fruited. These pilot experiments showed that plantation in the field (with young plants produced ex situ from seeds) was feasible for this species but the main problem was the subsequent seed germination and seedling establishment.

\section{Selection of sites for introductions}

Because $A$. bermejoi is known from only a single locality, there are no historical sites to be considered for reintroductions. As the first introduction was to some extent successful, it was decided to follow the same criteria employed by Rita \&
Cardona (2004a) for the choice of new localities, based on 1) habitat suitability (maximum similarity of geological, geomorphological and environmental characteristics compared to the original population) and 2) being located in a protected area, with 3) the agreement of the property owners, and 4) ease of accessibility.

The new locations selected were in the bed of a stream with a source in Punta de sa Font (PF), and a torrent located on the estate of Mongofre Vell (MV) $\left(39^{\circ} 59^{\prime} \mathrm{N}, 4^{\circ} 13^{\prime} \mathrm{E}\right)$. The two localities are separated from each other by approximately 500 $\mathrm{m}$ and are situated approximately $13 \mathrm{~km}$ from the original location (Fig. 2), and both are within the Natural Park of Albufera des Grau. Before planting, authorisation was obtained from the environmental authority (Govern de les Illes Balears) and property owners.

\section{Plant material used for introductions}

The introductions came from an accession collected under the LIFE2000NAT/E/7355 project and seeds collected on site in July 2007. From these plants we used two types of material: plants (rosettes of 8-12 leaves) obtained from the germination of seeds collected in situ and grown in cultivation, as well as plants generated from cuttings of plants propagated at the facilities of the University of the Balearic Islands (UIB) (late November 2007). The protocols for seed germination and ex situ cultivation are detailed in Cursach \& Rita (2012 a). Cuttings were made from terminal fragments of stolons with two rooting points, which were cut with a scalpel and planted in alveoli. The plants were kept in the experimental field of the UIB until being planted in the field (late February 2008).

\section{Planting method}

The planting method consisted of: 1) removal of the substrate and cleaning of the roots with water to minimise the introduction of external biological material (both water and substrate were removed from the area); 2) transplants were positioned in small groups of approximately ten individuals distributed in different microhabitats to maximise the chances of success; 3 ) each cluster comprised planted individuals from different parents to favour the genetic diversity; and 4) the identification of each of the individuals planted for subsequent monitoring.

\section{Monitoring and evaluation of the result of introductions}

We monitored monthly all individuals to assess the survival, flowering and fruiting rates. A study of the dynamics of the introduced populations (2008-2010) was carried out following the same protocol used for natural populations (see below). The progress of the introductions were assessed by the survival rate of individuals for the first three months after planting and the ratio of individuals that flowered and fruited for the first three reproductive periods (2008-2010). Statistical tests were applied to analyse differences in survival and fecundity (production of umbels per plant, umbel production per area) between plants produced from seed vs. from cuttings. Survival was treated as a binomial variable (alive / dead $=1 / 0$ ), and logistic regression was used to determine the effect of the type of plant (from seed vs. from cutting) on survival at three months 
Table 1. Characteristics of reintroduction projects carried out during the study period.

\begin{tabular}{llccccc}
\hline Type of project & Subpopulation & $\begin{array}{c}\text { Subpopulation } \\
\text { Code }\end{array}$ & Date & Type of plant material & $\begin{array}{c}\text { No. of parents } \\
\text { plants }\end{array}$ & $\begin{array}{c}\text { No. of } \\
\text { introduced } \\
\text { plants }\end{array}$ \\
\hline Introduction & Punta de sa Font & PF & February 2008 & Plants from seeds / from cutting & $23 / 19$ \\
Introduction & Mongofre Vell & MV & February 2008 & Plants from seeds / from cutting & $23 / 19$ & $63 / 32$ \\
Reinforcement & Cap Negre & CNe1 & March 2007 & Plants from seeds & $16 / 39$ \\
Reinforcement & Cudia Nova & CNo & February 2008 & Plants from seeds / from cutting & $5 / 5$ & 16 \\
Reinforcement & Cudia Nova & CNo & May 2010 & Plants from cutting & $18 / 12$ \\
unknown & 107 \\
\hline
\end{tabular}

after planting (GENLIN procedure). ANOVA was applied ( $\alpha$ $=0.05)$ to analyse significant differences between means of production of umbels per plant and per area depending on the type of plant (from seed vs. from cutting). Previously we checked the normality of the data using the non-parametric Kolmogorov-Smirnov and, if necessary, data was transformed (Quinn \& Keough, 2002). All statistical tests were performed using the statistical package SPSS Statistics v19.0.

\section{Reinforcements}

Table 1 shows a summary of the activities carried out in situ during the study period (2006-2010). In addition to introductions, we performed three reinforcements: one in the original location (CNe1) (2007), and two (2008 and 2010) in the introduced population in CNo in 2005. In the first case, we used plants grown from seeds, collected in situ, and germinated in culture (accession of LIFE 2000NAT/E/7355); in the other two cases, material was used from both plants derived from seed germination and also withand cuttings from cultivated plants (the cuttings derived from plants that came from seeds of the same accession, LIFE2000NAT/E/7355, and grown in the UIB and the Sóller Botanical Garden).

\section{Monitoring of natural and introduced populations}

Both the original ( $\mathrm{CNe}$ and $\mathrm{CNe} 2)$ and introduced subpopulations (CNo, PF and MV) were monitored monthly (bimonthly during the growing season of 2007) for four years (November 2006 - August 2010). This plant forms dense lawns of leaves and stems, so that its seeds tend to germinate very close together, and new plants grow to form clusters in which individuals very soon become indistinguishable. Consequently, commonly used demographic models (e.g., Easterling \& al., 2000; Caswell, 2001; Morris \& Doak, 2002; Ramula \& al., 2009) are not applicable for this species. In this work, we chose to monitor a "patch" of $A$. bermejoi as a sample unit, which could consist of one or more individuals. Each patch was identified according to its position in a two-axis system. The first was a fixed reference axis for each small group of patches (at PF and MV) or for the total population (CNe1, $\mathrm{CNe} 2$ and $\mathrm{CNo}$ ), indicated by marks (painted on rocks) aligned in the field. These marks allowed us to place tapes in exactly the same places in each census. The second axis was the distance from the center of each individual/patch relative to the reference axis. In each census, the length and width of all patches were measured to estimate their area of occupation. In the case of the introduced populations, the patches tended to develop less densely due to the greater moisture lev- el associated with the substrate, and we decided to apply estimates of the \% cover as a correction factor. Where possible, the information was collected at the individual level, scoring the developmental stage together with measurements and other observations that could be of interest (e.g., humidity, the presence of competing plants, erosion or accumulation of material). The following stages of the growth cycle were also noted: 1) seedlings (cotyledons present), 2) seedlings in an advanced stage (presence of cotyledons and first leaves), 3) leaf rosettes and 4) plants with stolons.

\section{Recruitment: survival of emerged seedlings}

We estimated the total number of seeds germinated in each population and year based on the total number of seedlings with cotyledons (isolated and inside patches) recorded in all censuses between autumn and the following spring. The survival of seedlings that germinated in the autumn for each population and year was evaluated at 3-4 months. Seedling survival was calculated from isolated seedlings, i.e., from seeds germinated outside of patches, which were therefore easily identifiable.

\section{Meteorological data and weather phenomena}

Data were available on the monthly rainfall, average temperature and average minimum and maximum temperatures (1998-2009), in addition to daily precipitation during the autumn (September 22 - December 21). All of these data were obtained at a weather station near CNe (La Mola " $39^{\circ} 52^{\prime} \mathrm{N}$, $4^{\circ} 19^{\prime} \mathrm{E}$ " and were provided by the State Meteorological Agency, AEMET).

\section{RESULTS}

\section{Assessment of the results of the introductions}

Three months after planting, the survival rate of the planted individuals was $59.0 \%$ at $\mathrm{PF}$ and $56.3 \%$ at MV, and most individuals surviving at beginning of summer (June) underwent flowering and fruiting (Table 2). In the autumn, seedlings were recorded (134 and 253 at PF and MV, respectively), noting the success in establishing new populations. The plants produced from cuttings showed a survival rate similar to that of the plant rosettes obtained from seed in both populations (PF-Wald $\chi 2$ $=3.698, \mathrm{df}=1, \mathrm{P}=0.054 ; \mathrm{MV}:-$ Wald $\chi 2=2.800, \mathrm{df}=1, \mathrm{P}=$ $0.094)$, although the production of umbels per plant was significantly higher in plants from cuttings (PF: F1, $32=11.26, \mathrm{P}$ $<0.01, \mathrm{MV}: \mathrm{F} 1,32=30.24, \mathrm{P}<0.01$; the data were transformed using the square root function). No difference was observed in the production of umbels per unit area (Fig. 3). 

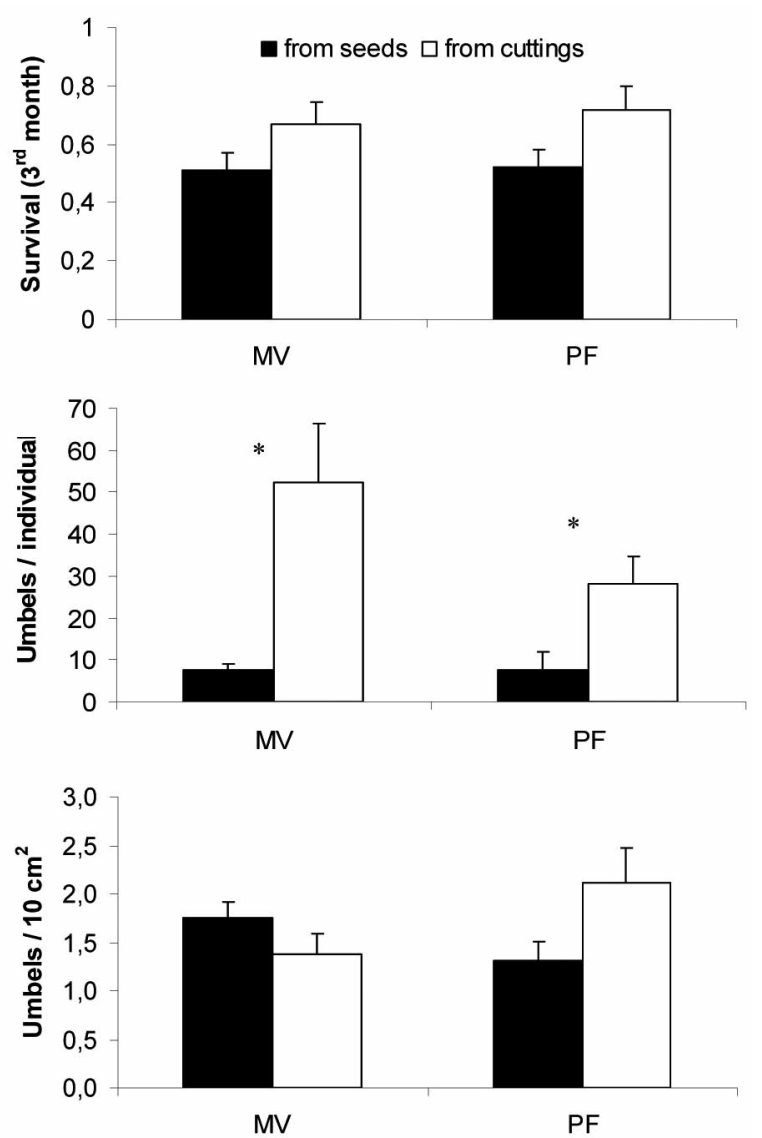

Fig. 3. Survival of plants, average ( \pm standard error) umbel production per plant and umbel production per unit of patch area for the two introduced populations of Apium bermejoi. Plant rosettes produced from seeds (black bars) and from cuttings (white bars); asterisks indicate significant differences (ANOVA, $\alpha=0.05$ ). MV, Mongofre Vell, PF, Punta de sa Font.

The caespitose growth form of the plants and the fact that the seeds germinate close together did not allow for individual monitoring of the plants beyond the first reproductive period. Therefore, the data for the second and third reproductive period refer to the entire population, and so comprising surviving planted individuals and also new individuals generated through both asexual reproduction and seed germination (see below). The number of patches that make up the population and the ratio of patches that produce flower and fruit decreased from the first to the third reproductive period (Table 2). However, for cover, which is the parameter that most closely approximates the size of the population, the values obtained in the third year were similar to those of the previous two years (see below).

\section{Dynamics of natural and introduced populations}

The population dynamics data are represented by two variables: the number of individuals and/or patches and the estimate of the cover for each censused population (Fig. 4-5). The data from autumn to autumn during the four periods studied show the same pattern. In autumn (October / November census), coinciding with the germination of seeds, there is a peak in the number of patches. Subsequently, this number decreases to show minimum values in the summer censuses, even reaching zero in the case of $\mathrm{CNo}$. In contrast, the occupation area also shows a minimum in summer (August / September), but with a peak in spring (May / June), when maximum vegetative development occurs. This seasonal pattern is generally observed for all of the studied populations, although those at $\mathrm{PF}$ and MV maintained higher cover during the summer than the original population at $\mathrm{CNe}$.

The number of patches in the original population $(\mathrm{CNe})$ at the time of maximal vegetative development (May / June) had fluctuated between a minimum of 18 (in 2000) and a maximum of 92 (in 1999), and the area of occupancy between 6.68 $\mathrm{dm}^{2}$ (in 2000) and $182.18 \mathrm{dm}^{2}$ (in 2010) (Fig. 6) (including data from 1999-2002 censuses; Mus \& al., 2003). The CNe2 population, which is located a few hundred meters from the original population, consists of a small number of patches (up to 6), and its maximum surface area occupancy recorded in the study period was $9.64 \mathrm{dm}^{2}$ (June 2010), representing only $5 \%$ of coverage at $\mathrm{CNe}$ (data not shown).

In the introduced population at $\mathrm{CNo}$, the dynamics in terms of coverage have fluctuated, but the number of patches recorded in the May / June censuses (excluding the individuals planted during reinforcements) has been declining $(2007=26,2008=15,2009=13$ and $2010=4)$. The individ uals planted during the reinforcements in 2008 and $2010 \mathrm{ac}-$ counted for $36.4 \%$ and $94.4 \%$ of the cover, respectively, providing two-thirds of the production of umbels in both cases (Table 3).

The PF and MV populations were introduced in February 2008 by planting 95 and 112 individuals, respectively (Fig. 5). In the census performed in June of that year, the PF population consisted of 46 patches occupying $63.92 \mathrm{dm}^{2}$ and the MV population of 50 patches occupying $99.61 \mathrm{dm}^{2}$. At both locations, the number of patches in the following 2009 reproductive period was lower, although the total areal extent of the population was considerably greater $\left(201.02 \mathrm{dm}^{2}\right.$ at $\mathrm{PF}$ and $229.87 \mathrm{dm}^{2}$ at MV). At both locations, the populations in June 2010 showed diminished cover values similar to those of the June 2008 census.

Table 2. Evaluation of the introductions, indicating the successful establishment (survival of planted individuals) and the ratios of flowering and fruiting. MV, Mongofre Vell; PF, Punta de sa Font.

\begin{tabular}{|c|c|c|c|c|c|c|c|c|c|c|c|c|c|c|}
\hline & \multicolumn{3}{|c|}{$\%$ survival } & \multicolumn{3}{|c|}{$1^{\text {st }}$ reproductive period } & \multicolumn{4}{|c|}{$2^{\text {nd }}$ reproductive period } & \multicolumn{4}{|c|}{$3^{\text {rd }}$ reproductive period } \\
\hline & $\begin{array}{c}1^{\text {st }} \\
\text { month }\end{array}$ & $\begin{array}{l}\text { 2nd } \\
\text { month }\end{array}$ & $\begin{array}{c}3^{\text {rd }} \\
\text { month }\end{array}$ & $\begin{array}{c}\text { No. } \\
\text { patches } \\
\text { (June) }\end{array}$ & $\begin{array}{c}\% \\
\text { flowering }\end{array}$ & $\begin{array}{c}\% \\
\text { fruiting }\end{array}$ & $\begin{array}{c}\text { No. } \\
\text { seedling }\end{array}$ & $\begin{array}{c}\text { No. } \\
\text { Patches } \\
\text { (June) }\end{array}$ & $\begin{array}{c}\% \\
\text { flowering }\end{array}$ & $\begin{array}{c}\% \\
\text { fruiting }\end{array}$ & $\begin{array}{c}\text { No. } \\
\text { seedling }\end{array}$ & $\begin{array}{c}\text { No. } \\
\text { patches } \\
\text { (June) }\end{array}$ & $\begin{array}{c}\% \\
\text { flowering }\end{array}$ & $\begin{array}{c}\% \\
\text { fruiting }\end{array}$ \\
\hline PF & 67.4 & 64.2 & 59.0 & 46 & 86.0 & 82.5 & 134 & 23 & 91.3 & 78.3 & 147 & 28 & 75.0 & 39.3 \\
\hline MV & 63.4 & 58.0 & 56.3 & 50 & 87.0 & 83.7 & 253 & 37 & 70.3 & 59.5 & 106 & 21 & 66.7 & 66.7 \\
\hline
\end{tabular}



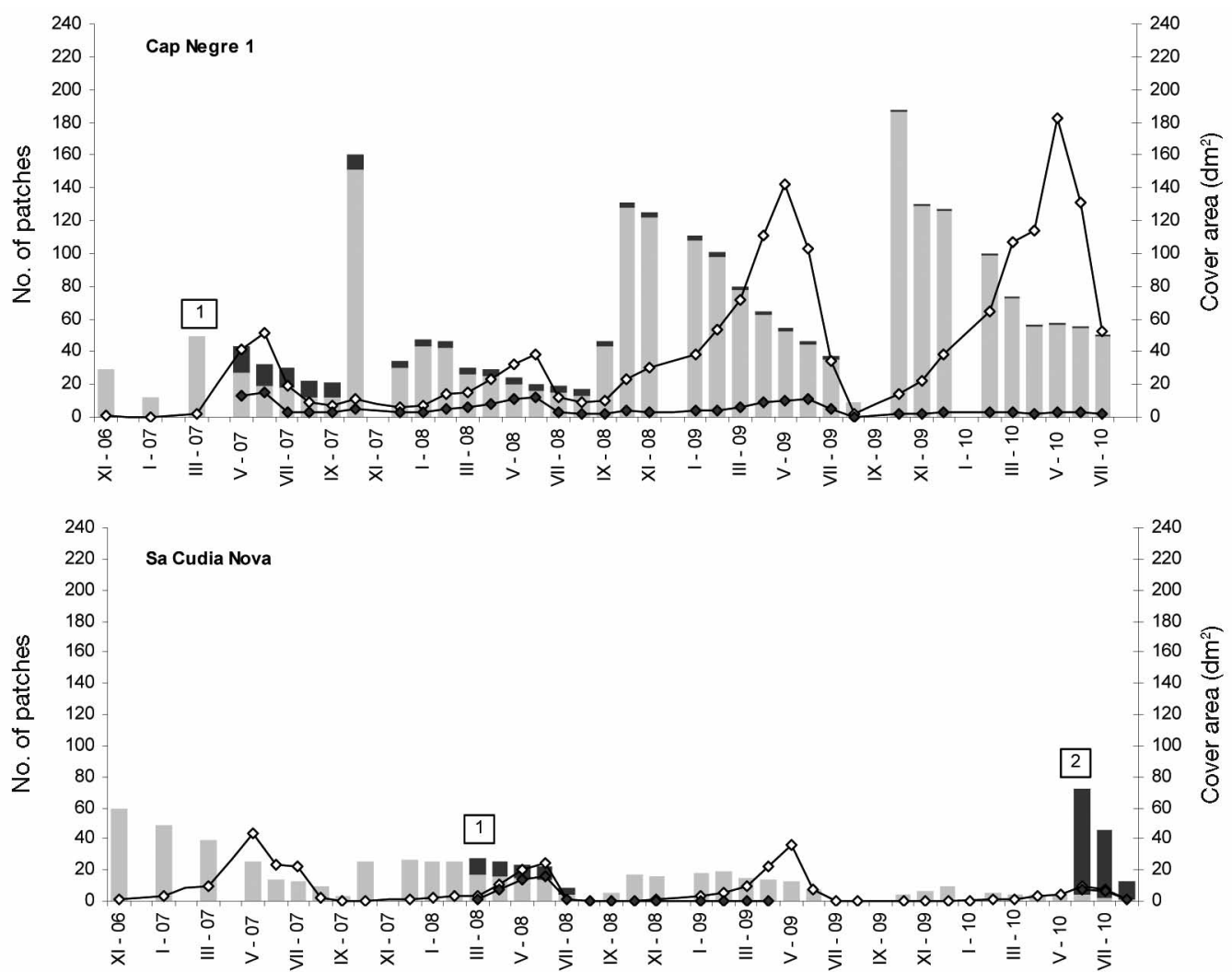

Fig. 4. Number and cover of patches of plants in the original population of Apium bermejoi (Cap Negre) and the population introduced in 2005 (Cudia Nova) (2006-2010). The bars indicate the number of patches (black bars indicate the patches arising from reinforcement). The lines represent the whole coverage area of the patches (open circles) and the coverage corresponding to planted individuals (filled circles). Cap Negre 1: 1, reinforced with 16 individuals; Cudia Nova: 1, reinforced with 30 individuals, and 2, reinforced with 107 individuals.

\section{Recruitment: survival of emerged seedlings}

In the original population at $\mathrm{CNe}$ most of the individuals/ patches that were found in the autumn censuses (October / November) were produced from seed germination (88-90\%). In the introduced population at $\mathrm{CNo}$, the new generation patches were $100 \%$ in three of four autumns monitored. In contrast, in the introduced populations at PF and MV (2008), the proportion of individuals that survived the summer and contributed to the population in the next season was higher (Table 4).

The number of seeds that germinated in situ was highly variable between years and locations (Table 5). At CNe, up to 1094 seedlings were recorded in autumn 2007, which is more than twenty times the number in the previous year. However, in the populations introduced in 2008 , the number of seed- lings that emerged in autumn did not show as much variability (Table 5). The survival of these seedlings in the three localities where $A$. bermejo $i$ was introduced was quite high, with values over $40 \%$ and in some cases exceeding $65 \%$, obtained in both years and locations (except CNo in 2009, where it was $28.6 \%)$. These values are much higher than those in the original population. The seedling survival in the original population did not exceed $40 \%$ in any of the four years studied and showed high variability, with a minimum $1.2 \%$ (autumn 2007) and a maximum 39, $2 \%$ survival (autumn 2008) being recorded (Table 6).

Furthermore, we found important correlates between germination and seedling survival at $\mathrm{CNe}$ with meteorological factors during 2006-2010. The autumn of 2006 which evinced a low germination (53 seedlings), and a low survival (6.9\%)

Table 3. Evaluation of the reinforcements, indicating the ratio of the survival of introduced plants to population originals and their ratios of flowering and fruiting in the first breeding season. The contribution of these plants to the whole population in terms of the number of patches and umbels produced is also shown.

\begin{tabular}{|c|c|c|c|c|c|c|c|c|c|}
\hline \multirow{3}{*}{ Subpopulation } & \multirow{3}{*}{ Date } & \multirow{3}{*}{$\begin{array}{c}1^{\text {st }} \\
\text { month }\end{array}$} & \multicolumn{2}{|c|}{$\%$ survival } & \multicolumn{5}{|c|}{$1^{\text {st }}$ reproductive period } \\
\hline & & & \multirow{2}{*}{$\begin{array}{l}2^{\text {nd }} \\
\text { month }\end{array}$} & \multirow{2}{*}{$\begin{array}{l}3^{\text {rd }} \\
\text { month }\end{array}$} & \multirow{2}{*}{$\begin{array}{l}\text { No. patches } \\
\text { (June) }\end{array}$} & \multirow{2}{*}{$\begin{array}{c}\% \\
\text { flowering }\end{array}$} & \multirow{2}{*}{$\begin{array}{c}\% \\
\text { fruiting }\end{array}$} & \multicolumn{2}{|c|}{ In relation to the total subpopulation } \\
\hline & & & & & & & & \% patches (June) & $\%$ umbels produced \\
\hline Cap Negre 1 & March 2007 & 100 & 100 & 93.8 & 13 & 92.3 & 76.9 & 38.7 & 22.9 \\
\hline Cudia Nova & February 2008 & 36.7 & 30.0 & 30.0 & 8 & 87.5 & 87.5 & 36.4 & 66.2 \\
\hline Cudia Nova & May 2010 & 64.5 & 42.1 & 11.2 & 68 & 76.5 & 66.2 & 94.4 & 65.1 \\
\hline
\end{tabular}


Table 4. Proportion of patches generated through new seed germination in autumn (October or November census) across the 4 reproductive periods in the study period.

\begin{tabular}{lcccc}
\hline & \multicolumn{4}{c}{ Proportion of patches from new seed germination } \\
\cline { 2 - 5 } Subpopulation & Autumn 2006 & Autumn 2007 & Autumn 2008 & Autumn 2009 \\
\hline Cudia Nova & $100 \%(n=60)$ & $88.5 \%(n=26)$ & $100 \%(n=17)$ & $100 \%(n=4)$ \\
Cap Negre 1 & $89.7 \%(n=29)$ & $87.5 \%(n=160)$ & $87.8 \%(n=132)$ & $90.4 \%(n=188)$ \\
Punta de sa Font & & & $75.7 \%(n=74)$ & $66.7 \%(n=60)$ \\
Mongofre Vell & & & $64.3 \%(n=84)$ & $71.9 \%(n=57)$ \\
\hline
\end{tabular}

Table 5. Total number of seeds that germinated in the autumn (X-XII) and winter (I-III) in the 4 monitored reproductive periods.

\begin{tabular}{lcrrrrrrr}
\hline & \multicolumn{2}{c}{$\mathbf{2 0 0 6 - 2 0 0 7}$} & \multicolumn{2}{c}{$\mathbf{2 0 0 7 - 2 0 0 8}$} & \multicolumn{2}{c}{$\mathbf{2 0 0 8 - 2 0 0 9}$} & \multicolumn{1}{c}{$\mathbf{2 0 0 9 - 2 0 1 0}$} \\
\cline { 2 - 8 } Subpopulation & X-XII & I-III & X-XII & I-III & X-XII & I-III & X-XII & I-III \\
\hline Cap Negre 1 & 53 & 43 & 1094 & 34 & 280 & 21 & 842 \\
Cap Negre 2 & $?$ & 3 & 5 & 0 & 2 & 1 & 7 \\
Cudia Nova & 78 & 2 & 113 & 4 & 33 & 4 & 0 \\
Punta de sa Font & & & & & 102 & 32 & 14 & 1 \\
Mongofre Vell & & & & & 189 & 64 & 21 \\
\hline
\end{tabular}

Table 6. Survival (\%) in the month of February of seedlings germinated during the previous autumn (hence, the 3 or 4 first months of life). The numbers $n$ in parentheses indicate the number of seedlings on which the percentage of survival was calculated.

\begin{tabular}{lrrrr}
\hline Subpopulation & $\mathbf{2 0 0 6 - 2 0 0 7}$ & $\mathbf{2 0 0 7 - 2 0 0 8}$ & $\mathbf{2 0 0 8 - 2 0 0 9}$ & $\mathbf{2 0 0 9 - 2 0 1 0}$ \\
\hline Cap Negre (original) & $6.9(n=29)$ & $1.2(n=686)$ & $39.2(n=79)$ & $27.6(n=471)$ \\
Cudia Nova & $42.9(n=35)$ & $30.1(n=103)$ & $68.2(n=22)$ & $28.6(n=7)$ \\
Punta de sa Font & & & $41.4(n=58)$ & $68.6(n=35)$ \\
Mongofre Vell & & $45.3(n=128)$ & $54.9(n=82)$ \\
\hline
\end{tabular}

corresponded with the driest autumn in the last 12 years (1998-2009) (83.3 mm of precipitation vs. an average of 229.2 $\mathrm{mm}$ for the September to November quarter); this was also the warmest autumn, with the average temperature of this November surpassed by $2.5^{\circ} \mathrm{C}$ that of the last 12 years for this month. This dry autumn was also preceded by a very dry spring. Therefore, the poor germination and seedling survival are reasonably attributable to this extreme event of an autumn drought accompanied by high temperatures.

The autumn of 2007 was relatively wet, and October of that year saw the highest seed germination documented thus far in the original population (1094 seedlings). However, in February of the following year, only $1.3 \%$ of these seedlings survived, which is the lowest rate of survival we have documented to date. In this case, the observed mortality was almost certainly caused by a heavy rainfall event that occurred in November of that year, when approximately $87 \%$ of the rain recorded during the month fell within just two days (of the same week), and a rainfall of $64 \mathrm{~mm}$ was observed in a single day. These intense rains heavily eroded parts of the torrent bed, while sediment accumulated in other parts, carrying away or covering most of the $A$. bermejoi seedlings (personal observations).

Finally, in the original population, a seedling survival of $39.2 \%$ was recorded in autumn 2008 , coinciding with the wettest autumn study period $(298.5 \mathrm{~mm})$ and a fairly regular rainfall regime (precipitation distributed across 42 days, only 2 of which received particularly heavy rainfall). In autumn 2009, relatively high seed germination was recorded, consis- tent with the high coverage values observed in the previous spring and a quite humid autumn.

\section{DISCUSSION}

\section{Assessment of the introductions of Apium bermejoi}

The data presented in this paper indicate that the two attempts at introduction (PF and MV) were successful according to the criteria of Menges (2008) and Godefroid \& al. (2011). Just over $50 \%$ of the plants grown at the two new locations survived 3 months after sowing, and over $80 \%$ of these plants flowered and fruited. Similarly, monitoring the survival ratios presented in this work, together with the ratios of flowering and fruiting recorded in these two populations over three breeding seasons (2008-2010) (Cursach \& Rita, 2012a), led to us believe that both populations exhibit a real potential to persist over time.

Seed germination occurred regularly every year in sufficient numbers to generate a population of similar size to the original, though somewhat smaller than that observed in the same years in the natural population. Recruitment is considered the most reliable parameter indicating the success of an introduction because it reflects the success of many of the life cycle processes, including survival and plant vigour, flower production, pollination, seed set, seed dispersal, and the presence of suitable areas for establishing recruits (Pavlik, 1996; Sutter, 1996). Therefore, we can conclude that, at least in the short term, the introductions were successful.

Regarding the type of material used, three months after 


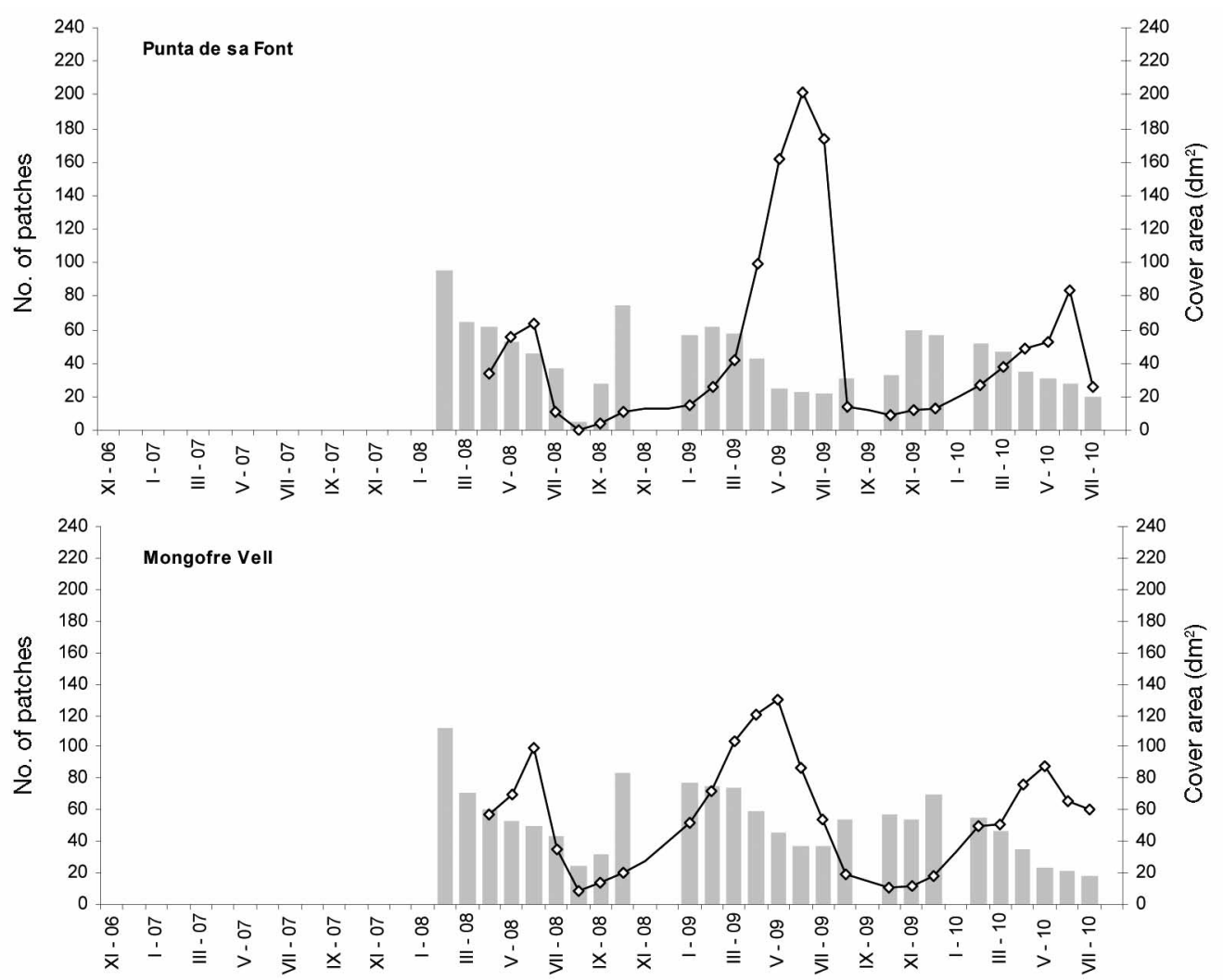

Fig. 5. Number and cover of patches of plants in the two populations introduced of Apium bermejoi in 2008: Punta de sa Font and Mongofre Vell (20082010). The bars correspond to the number of patches that form the subpopulations, and the lines represent the coverage areas of the plants of the subpopulations.

planting, the plants from cuttings showed a survival rate similar to the rosettes of plants generated from seeds in both introduced populations. Umbel production was higher in individual plants from cuttings, although umbel production per unit area was similar for both types of material. Thus, the higher plant fertility observed is not attributed to the type of material planted but the size of individuals, as at the time of planting, the plants produced from cuttings were larger than those from seeds cultivated ex situ, (data not shown). Production of plants via asexual methods is therefore an effective technique for restoring populations of $A$. bermejoi, if the origin of the material used is known, and plantations with a high proportion of plants from the same clone are not performed because an inappropriate use of asexually produced plants could modify the original allelic ratios.

However, the population introduced in $2005(\mathrm{CNo})$ had difficulty in regenerating autonomously, and the reinforcements of this population conducted in 2008 with 30 transplants derived from seeds grown ex situ and cuttings of plants grown ex situ and in 2010 with 107 individuals derived from cuttings have been essential for its maintenance (plants from the reinforcements contributed $66.1 \%$ of the population coverage in 2008 and $70.9 \%$ in 2010). There is no single obvious cause for this unfavourable situation, but rather, it is attributed to a combination of several factors related to 1 ) the physical characteristics of the site, as the torrent bed dried earlier than at the other localities; 2) competition with other plants: the areas favourable for the establishment of $A$. bermejo $i$ have been colonised mostly by Polypogon maritimus Willd. ssp. subsphataceus (Req) Bonnier et Layens and Parapholis incurva (L.) C.E. Hubbard, forming dense graminoid turfgrass; and 3) predation by insects: we have noted the presence of phytophagous caterpillars (of Orthonama obstipata Fabricius (Geometridae), det. M.A. Miranda and V. Sarto) that prey on the vegetative structures of $A$. bermejoi (these caterpillars have also been observed in the ex situ population and at the other localities where $A$. bermejo $i$ was introduced, but not in the original population). We have also noted seed predation and possible dispersal by ants (Messor bouvieri), both at this locality and at MV, although the intensity of this predation has not been assessed (Cursach \& Rita, 2012a).

Because the Cudia Nova site can support a population of A. bermejoi, provided that there is an annual reinforcement of it, we considered it to be a good site to conduct experimental management activities, or scientific experiments in a natural environment. Additionally, this population could even be used as a bridge between ex situ and in situ cultivation in the sense proposed by Volis \& Blecher (2010).

\section{Dynamics of natural and introduced populations}

Demographic information (e.g., data on the distribution, structure and dynamics of natural populations) is key to understanding the current status of an endangered species and for estimating their future viability (Schemske, 1994; García, 2002). The only available data on the structure and demogra- 

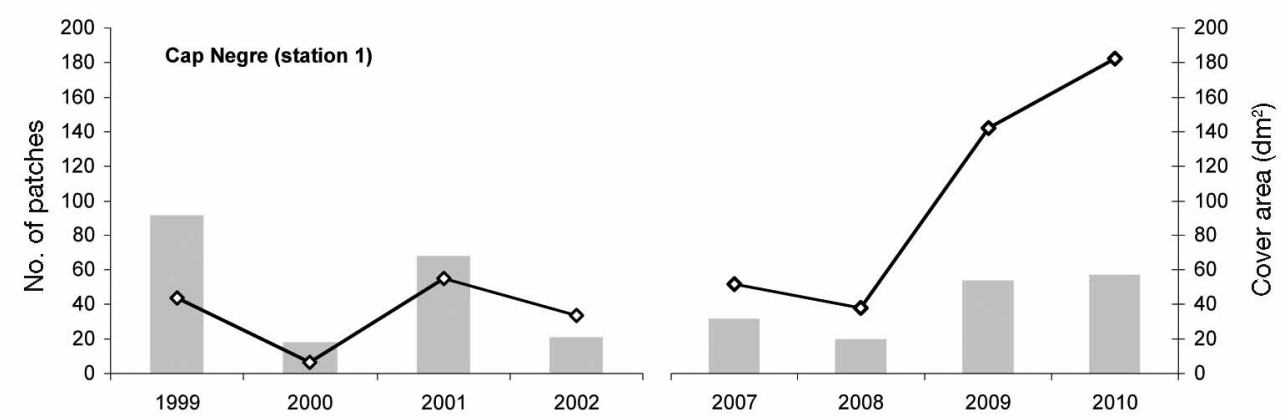

Fig. 6. Number of patches (bars) and coverage area (lines) of Apium bermejoi during the periods 1999-2002 (source: Mus \& al., 2003) and 2007-2010 (data from this study) at the original locality (Cap Negre 1). The data refer to the period of maximum vegetative development (May / June).

phy of $A$. bermejoi at its original location were for the years 1999-2002 (Mus \& al., 2003) and 2006-2010 (the subject of this paper). The data showed that the population at $\mathrm{CNe}$ exhibited strong fluctuations, always presenting very low numbers (at the time of maximum vegetative growth the number of patches fluctuated between 18 and 92 and the area of occupancy between $6.68 \mathrm{dm}^{2}$ and $182.18 \mathrm{dm}^{2}$ ).

The "number of individuals / patch" parameter is of interest for comparing the state of the population at a locality between different years, but it does not accurately reflect population demography over an annual growing period. This is because at the time of maximum plant growth (April-June), several individual plants can be united into a single patch, which is reflected in a graph in a declining population that is not real. By contrast, the decline observed in summer (JulySeptember) corresponds to the mortality that occurs at this time of year.

In contrast, the area of occupancy, or cover, showed a different and more realistic pattern: the values were minimal in August / September censuses (when only surviving plants that had withstood the summer were recorded). Subsequently, during autumn an increase in coverage was observed with the growth of new seedlings, reaching a peak in May / June, after which the coverage was reduced to the minimum values of summer.

In the autumn census, the proportion of newly generated individuals, i.e., from seed germination, was quite high in the original location, where approximately $90 \%$ of the plants in October / November belonged to the new generation, but with significant variations depending on the year and location. Therefore, although this species has been considered a hemicryptophyte, as noted by Llorens (1982) and Fraga \& al. (2004), under natural conditions, its more general life form is therophyte. Additionally, we have found that if soil moisture conditions are maintained for a longer period, as in the populations introduced in 2008, the proportion of plants that survive the summer was greater. For this reason, a factor that determined the cycle of this plant, and certainly the ratio of plants produced from seeds and that live for more than a year, was the period of time that the soil remains moist, which in turn, depended on the weather in each year and the characteristics of the torrent. In either case, recruitment was a critical phase for the maintenance of natural populations and species conservation.

\section{Biology of reproduction: relationship with meteorological and climatic factors}

The distribution and intensity of precipitation in autumn determines the seedling survival success. The strong or torrential rainfall (> $64 \mathrm{~mm}$, Homar \& al., 2010) that occurs mainly in autumn causes substantial changes in the bed of the torrent, mainly in the form of soil erosion and accumulation of drift material, most likely causing seed loss. Furthermore, the length of the dry periods also directly affects the survival of seedlings, especially if they occur during the autumn and are accompanied by high temperatures. According to these observations, climate change scenarios could compromise the seedlings survival. For the Balearic Islands, a decreasing trend of annual rainfall and an increased variation in daily rainfall that is weak to moderate $(0-16 \mathrm{~mm})$ or torrential $(>64 \mathrm{~mm})$, along with an increase in maximum temperatures (approximately $5^{\circ} \mathrm{C}$ per century), have been predicted (Homar \& al., 2010). Therefore, extreme weather events, such as heavy rainfall or heat waves in the reproductive period (late spring and early summer), are also a substantial risk to the future of this species.

\section{Current state of conservation and future threats}

Based on observations made over the 4 years of monitoring conducted in the present study, the major environmental threats that currently affect the establishment and maintenance of $A$. bermejoi are 1) the large annual fluctuations in the number of seedlings that become established that are sometimes generated by extreme weather events; 2 ) the increases in such extreme weather events (heavy rains, heat waves) due to global warming; and 3) the reduced availability of suitable habitats for this species, which limits the area of sites where the plant can live; which are exacerbated by 4 ) the presence of competing plant species that limit the development of $A$. bermejoi; and 5) phytophagous insect predation. On other hand, direct anthropogenic threats are less important at this time but deserve to be taken into account. For example, occasional tilling of lands in the catchment area of the torrent where this species lives results in materials being carried away by rain, which are then deposited on the bed of the torrent where $A$. bermejoi lives. It is also possible that these farming activities increase the eutrophication of the torrent and that they are the cause of the growth of filamentous algae, which also appear to be detrimental to the development of $A$. berme- 
joi. Furthermore, the frequent use of the area by motocross riders is a dangerous threat that has been latent for many years.

A species with a single population is vulnerable to extinction simply due to being subject to factors that vary stochastically, which is why the introduction of species in new locations greatly increases their chances of survival (Maunder, 1992). In this sense, the actions taken in the present study have helped restore the original population of $A$. bermejoi and reduced its probability of extinction by increasing the number of populations of this plant in the wild, and so providing additional sources for seed collection for use in ex situ techniques, without disturbing the natural regeneration capacity of the original population. The short-term follow-up investigation described herein revealed that the introductions have been successful, although long-term monitoring will be essential to confirm their resilience (resistance to disturbance) and persistence (autonomous maintenance) (Pavlik, 1996).

In the last version of the Red List of Spanish Vascular Flora published (Moreno, 2008), A. bermejoi is listed as Critically Endangered by the criteria of B1ac (iv) +2 ac (iv); D. That is, the requirements are met regarding the extent of occurrence $<100 \mathrm{~km}^{2}$ and area of occupancy $<10 \mathrm{~km}^{2}$, existence in only one location and extreme fluctuations based on the number of mature individuals; moreover, the number of mature individuals is $<50$. However, if in coming years, the state of the introduced populations remains as has been observed thus far, this situation could be modified, and we are of the opinion that the threat category of this species could shift from Critically Endangered to Endangered.

\section{ACKNOWLEDGEMENTS}

We thank Dra. E. Moragues, X. Cardona, J.M. Castro, A. Mateu and M.A. Cerdà their help in field work. We thank Dr. M.Á. Miranda (Universitat de les Illes Balears) and V. Sarto (Departament d'Agricultura, Ramaderia, Pesca, Alimentació i Medi Natural de la Generalitat de Catalunya) the identification of specimens of Lepidoptera. We are grateful to the farm owners of Sant Antoni, Mongofre Vell, Sa Cudia Nova and Son Camamil-la the facilities that we had to work on their farms, and the staff of the Albufera des Grau Natural Park for their logistical support. For the development of this research, J. Cursach received a grant from the Conselleria d'Economia, Hisenda i Innovació del Govern de les Illes Balears. This work was funded by the Conselleria de Medi Ambient del Govern de les Illes Balears, the Consell Insular de Menorca and MAVA Foundation, and partly carried out within the activities of the Recovery Plan of Apium bermejoi approved by the Govern de les Illes Balears and published in the BOIB $\mathrm{n}^{\circ} 65$ of 15/05/2008.

\section{REFERENCES}

Aboucaya, A., Guyot, I., Piazza, C. \& Virevaire, M. 1999. Plans dé gestion conservatoire mis en place en Corse pour cinq especes végétales endémiques et prioritaires de la Directive "Habitats". Bulletin de la Société Botanique du Centre-Ouest, numéro espécial 19: 251-269.

Caswell, H. 2001. Matrix populations models. Construction, analysis and interpretation. Ed. Sinauer Associates. Sunderland, MA.

Colas, B. E al. 2008. Restoration demography: a 10-year demographic comparison between introduced and natural populations of endemic Centaurea corymbosa (Asteraceae). Journal of Applied Ecology 45: 1468-1476.

Cursach, J. \& Rita, J. 2012a. Reproductive biology and reproductive output assessment in natural and introduced subpopulations of Apium bermejoi, a 'Critically Endangered' endemic plant from Menorca (western Mediterranean). Nordic Journal of Botany 30: 754-768.

Cursach, J. \& Rita, J. 2012b. Reproductive biology of Ranunculus weyleri (Ranunculaceae), a narrowly endemic plant from the Balearic Islands with disjunct populations. Flora, http://dx.doi.org/10.1016/j.flora.2012. 07.004

Cursach, J., Rita, J., Mateu, A. \& Castro, J.M. 2009. Conservation study of an endemic plant of the Balearic islands endangered to become extinct: Apium bermejoi L. Llorens (Apiaceae). In: Bacchetta, G. (ed.), Biodiversity hotspots in the Mediterranean Area: species, communities and landscape level. Book of Abstracts: 275. Ed. Centro Conservazione Biodiversità. Cagliari.

Easterling, M.R., Ellner, S.P. \& Dixon, P.M. 2000. Size-specific sensitivity: applying a new structured population model. Ecology 81: 694-708.

Escudero, A. \& Iriondo, J.M. 2003. Restauración de poblaciones de plantas amenazadas. In: Rey, J.M., Espigares, T. \& Nicolau, J.M (eds.), Restauración de ecosistemas mediterráneos: 113-139. Colección Aula Abierta, n. ${ }^{\circ}$ 20, Servicio de Publicaciones de la Universidad de Alcalá. Madrid.

Fahselt, D. 2007. Is transplanting an effective means of preserving vegetation? Canadian Journal of Botany 85: 1007-1017.

Falk, D.A., Millar, C.I. \& Olwell, M. 1996. Guidelines for developing a rare plant reintroduction plan. In: Falk, D.A., Millar, C.I. \& Olwell, M. (eds.), Restoring diversity: Strategies for reintroduction of endangered plants: 454 490. Island Press, Washington.

Fiedler, P.L. \& Laven, R.D. 1996. Selecting reintroduction sites. In: Falk. D.A., Millar, C.I. \& Olwell, M. (eds.), Restoring diversity: Strategies for reintroduction of endangered plants: 157-169. Island Press, Washington.

Fraga, P. 2000. Intentos de reintroducción de Lysimachia minoricensis J.J. Rodr. en Menorca. Conservación Vegetal 5: 12.

Fraga, P., Mascaró, C., Carreras, D., García, O., Pellicer, X., Pons, M., Seoane, M. \& Truyol, M. 2004. Catàleg de la flora vascular de Menorca. Ed. Institut Menorquí d'Estudis, Maó.

García, M.B. 2002. Interés de los estudios demográficos en la conservación. Catalogación de especies amenazades. In: Bañares, A. (ed.), Biología de conservación de plantas amenazadas: 15-25. Ed. Organismo Autónomo de Paques Nacionales, Madrid.

Godefroid, S. \& Vanderborght, T. 2011. Plant reintroductions: the need for a global database. Biodiversity and Conservation, doi: 10.1007/s10531011-0120-2.

Godefroid, S., Piazza, C., Rossi, G., Buord, S., Stevens, A.D., Aguraiuja, R., Cowell, C., Weekley, C.W., Vogg, G., Iriondo, J.M., Jonson, I., Dixon, B., Gordon, D., Magnanon, S., Valentin, B., Bjureke, K., Koopman, R., Vicens, M., Virevaire, M. \& Vanderborght, T. 2011. How successful are plant species reintroductions? Biological Conservation 144: 672-682.

Guerrant, E.O. \& Kaye, T.N. 2007. Reintroduction of rare and endangered plants: common factors, questions and approaches. Australian Journal of Botany 55: 362-370.

Guerrant, E.O. \& Pavlik, B.M. 1998. Reintroduction of rare plant: genetics, demography and the role of ex situ conservation methods. In: Fiedler, P.L. \& Kareiva, P.M. (eds.), Conservation biology for the coming decade: 80-108. Chapman \& Hall, New York.

Heywood, V.H. \& Iriondo, J.M. 2003. Plant conservation: old problems, new perspectives. Biological Conservation 113:321-335.

Hodder, K.H. \& Bullock, J.M. 1997. Translocations of native species in the UK: implications for biodiversity. Journal of Applied Ecology 34: 547-565.

Homar, V., Ramis, C., Romero, R. \& Alonso, C. 2010. Recent trends in temperature and precipitation over the Balearic Islands (Spain). Climatic Change 98: 199-211.

Ibáñez, O., Calero, C., Mayol, M. \& Rossello, J.A. 1999. Isoenzime uniformity in a wild extinct insular plant, Lysimachia minoricensis J.J. Rodr. (Primulaceae). Molecular Ecology 8: 813-817.

IUCN. 1998. IUCN Guidelines for Re-introductions. Prepared by the IUCN/SSC Reintroduction Specialist Group, IUCN, Gland and Cambridge.

Knees, S.G. 2003. Apium L. In: Castroviejo, S. (coord.), Flora iberica 10: 269 275. Ed. Real Jardín Botánico, CSIC, Madrid.

Llorens, L. 1982. Un nuevo endemismo de la isla de Menorca: Apium bermejoi. Folia Botanica Miscelanea 3: 27-33

Martinell, M.C., López-Pujol, J., Blanché, C., Molero, J. \& Sáez, Ll. 2011. Conservation assessment to Aquilegia paui (Ranunculaceae): a case study of an extremely narrow endemic. Oryx 45(2): 187-190.

Maunder, M. 1992. Plant reintroduction: an overview. Biodiversity and Conservation 1:51-61.

Mayol, J., Moragues, E, Ramos, I. \& Tena, D. 2011. Flora rara versus amenazada. El caso de Euphorbia margalidiana. In: Rita, J. \& al. (eds.), Programa 
y libro de resúmenes del $V$ Congreso de Biología de la Conservación de Plantas: 49. Ed. Universitat de les Illes Balears-SEBICOP, Palma.

Menges, E.S. 2008, Restoration demography and genetics of plants: when is a translocation successful? Australian Journal of Botany 56: 187-196.

Milton, S.J., Bond, W.J., Du Plessis, M.A., Gibbs, D., Hilton-Taylor, C., Linder, H.P., Raitt, L., Wood, J. \& Donaldson, J.S. 1999. A protocol for plant conservation by translocation in threatened lowland fynbos. Conservation Biology 13: 735-743.

Montmollin, B., Strahm, W. \& UICN/CSE. 2007. La lista "Top 50" de especies vegetales amenazadas de las islas del Mediterráneo. Unión Mundial para la Naturaleza (UICN). Gland.

Moragues, E. \& Mayol, J. 2011. Managing threatened Plants in Islands; Task \& Priorities. In: II Jornades de Botànica a Menorca. Illes i Plantes: conservació $i$ coneixement de la flora a les illes de la Mediterrània: 8-9. Ed. CIMEIME-UIB, Maó

Moreno, J.C. (coord) 2008. Lista Roja 2008 de la flora vascular española. Dirección General de Medio Natural y Política Forestal (Ministerio de Medio Ambiente, y Medio Rural y Marino, y Sociedad Española de Biología de la Conservación de las Plantas), Madrid.

Morris, W.F. \& Doak, D.F. 2002. Quantitative conservation biology. Theroy and practice of population viability analysis. Ed. Sinauer Associates. Sunderland, Mass.

Mus, M., Rita, J., Moragues, E., Cardona, X. \& Conesa, M.A. 2003. Pla de gestió $i$ conservació de l'espècie Apium bermejoi (Projecte LIFE2000 NAT/E/7355). Laboratorio de Botánica del Dpto. de Biología de la Universitat de les Illes Balears, Palma. (Ined.).

Pavlik, B.M. 1996. Defining and measuring success. In: Falk, D.A., Millar, C.I. \& Olwell, M. (eds.), Restoring diversity: Strategies for reintroduction of endangered plants: 127-155. Island Press, Washington, DC.

Quinn, G.P. \& Keough, M. 2002. Experimental design and data analysis for biologists. Cambridge, New York.

Ramula, S., Rees, M. \& Buckley, Y.M. 2009. Integral projection models perform better for small demographic data sets than matrix population models: a case study of two perennial herbs. Journal of Applied Ecology 46: 1048-1053.

Rita, J. \& Cardona, X. 2004a. Pla d'introducció d'Apium bermejoi. Estudi elaborat pel projecte "Conservació d'àrees amb flora amenazada a l'illa de Me- norca" (Projecte LIFE2000NAT/E/7355). Laboratorio de Botánica del Dpto. de Biología de la Universitat de les Illes Balears, Palma. (Ined.).

Rita, J. \& Cardona, X. 2004b. Informe final del conveni entre el Consell Insular de Menorca i la UIB per al desenvolupament del projecte "Conservació d'àrees amb flora amenazada a l'illa de Menorca" (Projecte LIFE2000 $N A T / E / 7355)$. Laboratorio de Botánica del Dpto. de Biología de la Universitat de les Illes Balears, Palma. (Ined.).

Rita, J., Cardona, J., Moragues, E. \& Rosselló, J.A. 2005. Plan de conservación de Apium bermejoi Ll. Llorens (Apiaceae). Principales criterios y actuaciones. Programa y libro de resúmenes del II Congreso de Biología de la Conservación de Plantas: 99. Ed. Jardín Botánico Atlántico-SEBICOP, Gijón.

Ronse, A.C., Popper, Z.A., Preston, J.C. \& Watson, M.F. 2010. Taxonomic revision of European Apium L. s.l.: Helosciadium W.D.J. Koch restored. Plant Systematics and Evolution 287: 1-17.

Rosselló, J.A. 2004. Estudi de la variabilitat genètica d'Apium bermejoi. Estudi elaborat pel projecte "Conservació d'àrees amb flora amenazada a l'illa de Menorca" (Projecte LIFE2000NAT/E/7355). Laboratorio de Botánica del Dpto. de Biología de la Universitat de les Illes Balears, Palma. (Ined.).

Sainz-Ollero, H. \& Hernández-Bermejo, J.E. 1979. Experimental reintroductions of endangered plant species in their natural habitats in Spain. Biological Conservation 16: 195-206.

Schemske, D.W., Husband, B.C., Ruckelshaus, M.H., Goodwillie, C., Parker, I.M. \& Bishop, J.G. 1994. Evaluating approaches to the conservation of rare and endangered plants. Ecology 75: 584-606.

Seddon, P.J. 1999. Persistence without intervention: assessing success in wildlife reintroductions. Trends in Ecology and Evolution 14: 503.

Sutter, R.D. 1996. Monitoring. In: Falk, D.A., Millar, C.I. \& Olwell, M. (eds.), Restoring diversity: Strategies for reintroduction of endangered plants: 235264. Island Press, Washington, DC.

Valdés, B. 2011. Plant species protection in Spain, with especial reference to the Spanish Mediterranean Islands. Naturalista Sicil. S. IV, XXXV (1): 79-86.

Volis, S. \& Blecher, M. 2010. Quasi in situ: a bridge between ex situ and in situ conservation of plants. Biodiversity and Conservation 19: 2441-2454.

Associate Editor: Pablo Vargas Received: 24-XI-2011 Accepted: 11-IV-2013 